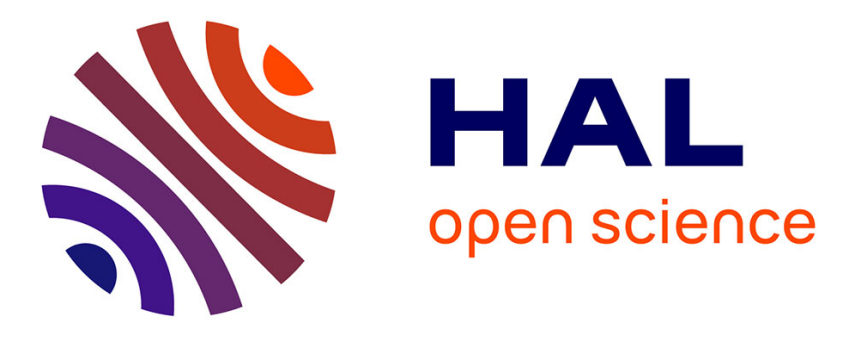

\title{
Sketching the Landscape for Lean Digital Transformation
}

\author{
Alireza Ashrafian, Daryl J. Powell, Jonas A. Ingvaldsen, Heidi C. Dreyer, \\ Halvor Holtskog, Peter Schütz, Elsebeth Holmen, Ann-Charlott Pedersen, \\ Eirin Lodgaard
}

\section{To cite this version:}

Alireza Ashrafian, Daryl J. Powell, Jonas A. Ingvaldsen, Heidi C. Dreyer, Halvor Holtskog, et al.. Sketching the Landscape for Lean Digital Transformation. IFIP International Conference on Advances in Production Management Systems (APMS), Sep 2019, Austin, TX, United States. pp.29-36, 10.1007/978-3-030-30000-5_4. hal-02419191

\section{HAL Id: hal-02419191 \\ https://hal.inria.fr/hal-02419191}

Submitted on 19 Dec 2019

HAL is a multi-disciplinary open access archive for the deposit and dissemination of scientific research documents, whether they are published or not. The documents may come from teaching and research institutions in France or abroad, or from public or private research centers.
L'archive ouverte pluridisciplinaire HAL, est destinée au dépôt et à la diffusion de documents scientifiques de niveau recherche, publiés ou non, émanant des établissements d'enseignement et de recherche français ou étrangers, des laboratoires publics ou privés. 


\title{
Sketching the Landscape for Lean Digital Transformation
}

\author{
Alireza Ashrafian ${ }^{1}$, Daryl J. Powell ${ }^{1}$, Jonas A. Ingvaldsen ${ }^{1}$, Heidi C. Dreyer ${ }^{1}$, Halvor \\ Holtskog ${ }^{1}$, Peter Schütz ${ }^{1}$, Elsebeth Holmen ${ }^{1}$, Ann-Charlott Pedersen ${ }^{1}$, Eirin Lodgaard ${ }^{2}$ \\ ${ }^{1}$ Department of Industrial Economy and Technology Management, Norwegian University of \\ Science and Technology, Trondheim 7491, Norway \\ ${ }^{2}$ SINTEF Raufoss Manufacturing, 2830 Raufoss, Norway \\ alireza.ashrafian@ntnu.no
}

\begin{abstract}
Lean management remains the most popular approach to operational excellence within industry. The next wave of industrial improvement is widely considered to be driven by the application of digital technologies. Organizations are seeking to understand how the two approaches can be utilized synergistically. This paper aims to sketch the landscape for current theories and managerial challenges facing Lean and digital transformation based on Lean principles with respect to organizational design, supply chain planning, decision systems and supplier relationships. We raise fundamental questions that should be addressed by future research in the field of digital lean manufacturing and lean digital transformations.
\end{abstract}

Keywords: Lean Management, Digital Transformation, Organization Design, Supply Chain Planning, Decision Systems, Supplier Relationships

\section{Introduction}

For several decades, improvement efforts in organizations have built on the concept of "Lean Thinking" and related ideas of process standardization and continuous improvement [26]. The next wave of industrial improvement is widely considered - within industry and academia alike - to be driven by the application of digital technologies $[18,28]$. Hence, there is growing appreciation among managers of the need to understand how these new digital technologies can be put to good use in order to improve efficiency and competitiveness.

Digital Lean manufacturing refers to the application of digital technology in order to enhance the Lean and learning transformation in manufacturing organizations. Ekanbans, digital problem solving, or kaizen in digital collaborative environments are some examples. In a recent article, Romero et al. [29] discussed the emergence of Digital Lean Manufacturing and the significance of digital waste that may that may come into existence in the cyber world due to the non-use (e.g. lost digital opportunities) 
and/or over-use (e.g. abused digital capabilities) of new digital/smart manufacturing technologies.

On the other hand, industrial experience suggests that too often technology adoption happens according to a "technology push" model: some technological component is developed or bought, and work processes are adapted to fit the technology. Technology pushes often contradict the key Lean principle that technology should serve the people and the processes [22]. Lean digital transformation, therefore, refers to the application of Lean principles to digitalization processes in order to achieve a digital transformation that creates less waste.

Management research on Lean and digitalization is still in its infancy [4, 32], as it remains poorly understood which organization models and principles make possible the best utilization of the new digital technologies [2]. This paper aims to sketch the landscape for Lean and digitalization joint transformation. We propose that novel theoretical insights can be developed by framing the relationship between the two.

\section{Frontiers of knowledge and technology}

\subsection{Lean Management}

Lean management, as popularized by Womack et al. [35], was ultimately a description of the philosophy and production system of the Japanese car manufacturer Toyota. Lean was subsequently presented as the global solution to improve efficiency and quality [13]. Lean has evolved over time and been embraced by other industries and in other cultures than that of its origin [26]. Five fundamental principles have been claimed to be universally applicable [36]: specification of value, identification of value streams, continuous flow, customer pull and striving for perfection. Netland \& Powell [26] recently proposed a further abstraction in that Lean, cut to the core, is about continuous improvement and three essential Ls: Learning, Leadership, and Long-term perspective. In their recent book, Ballé et al. [1] challenged organizations' traditional understanding and practicing of Lean by putting forward the Find-Face-Frame-Form strategy as a fresh new approach to understand the "true" Lean vs. the "false" one, i.e., Lean without learning. Yet, the practical application of Lean usually involves using a set of techniques such as just-in-time logistics, standardized work procedures, supplier feedback, reduction of set-up times, total quality management and statistical process controls [33].

\subsection{Digital manufacturing technologies}

As a result, from a future-oriented project, the German government coined "Industry 4.0" at the Hannover trade fair in 2011. New concepts, like Cyber-Physical System, Internet of Things, Big Data, Digital Twin, Block Chain and collaborative robot were introduced. Some of these concepts are old technologies recombined in new ways, and 
often incorporated with new technologies [12]. The overreaching goal of Industry 4.0 is to create highly flexible, yet high volume production lines, making processes more efficient and robust as well as reducing costs and improving the quality [21].

All of these technologies are powerful by themselves and create new opportunities, however, the core value of digitalization remains in true value creation for the customers, and at its core, to enhance "connectivity". This connectivity can be divided into two dimensions, internal and external. Internal connectivity deals with how to connect seamlessly different technologies and work processes inside the organization [28, 32]. The external connectivity relates to data flows, system integration, etc. between companies. Important and essential quality information can be shared using the Internet of Things technology [3].

\section{The Landscape}

The topic of Lean and digital transformation is fairly new and complex and it requires insight from several disciplines. In order to bring further clarity into challenges associated with Lean and digitalization interactions, a fairly extensive literature review was performed during the course of this study. As a result, four categories for further research are proposed. These categories correspond to four theoretical domains that are: organization theory, operations management, operations research and inter-organizational business relationships. In this section, each of these categories are briefly explained and some outstanding questions that ought to be addressed by further research are put forward.

\subsection{Organizational design}

The Lean work organization is characterized by both functional integration and integration of performance and control $[5,15]$. Extensive involvement of operators is premised on this organization design, as it empowers the shop floor vis-à-vis specialist functions. Digital technologies can support such an organization design, by providing faster and more reliable information for operational decision-making and continuous improvement activities [32]. If the technology is designed with this purpose, the relationship between Lean and digitalization may be synergistic. However, these synergies are not realized if the digitalization drives an organization-wide redistribution of decision-making power in favor of ICT-specialists organized in staff functions. For several reasons, such a redistribution of power is a likely development. Firstly, knowledge about how to design, configure and maintain the technologies will be a scarce resource, making the shop floor more dependent on outside expertise. Secondly, the big investments associated with digital technologies call for organization-wide standardization of technology, limiting the shop floor's discretion on the choice of technology and how to operate it. Thirdly, when continuous improvement becomes more analytical and datadriven, it relies more heavily on theoretical knowledge and require a deeper understand-

ing of statistics. Hence, it may likely become the domain of experts, rather than shop 
floor workers [14]. These tendencies clearly contradict the Lean principles of creating functional integration at the shop floor.

To address these challenges, the following questions can be put forward:

- How are the collaboration between the shop floor and ICT-specialists reconfigured considering digitalization?

- How can digital technology be designed to support functional integration at the shop floor?

- How may shop-floor workers and managers be trained to master the digital technologies, so that they retain participation in continuous improvement activities?

\subsection{Supply chain planning}

Supply chain planning aims to improve performance in operations by mitigating uncertainty through managing operations and customer demand, and coordinate supply chain activities with business strategy. With principles leading to elimination of waste, improving quality, cost reduction and increasing flexibility, the Lean concept has strongly influenced existing planning models and made planning highly sensitive to disturbance and variability [7, 9]. However, driven by technology combined with shifting supply and market complexity such as globalization, customization and serving individual needs instead of market categories [3], variability and uncertainty increases. While planning is becoming more demand and event driven (real-time, increased frequency, shorter planning horizon and cross functional), and turned into a process within the supply chain rather than in individual companies, the complexity and uncertainty increases [16].

Information technology strongly facilitates planning models by efficiently allowing access to information, advanced analytics and integrating operations between supply chain partners and across functions, which is crucial in most Lean programs [24]. However, technology may also come into conflict with Lean or in short of unlocking the potential by a standardized functionality and design, hindering the support of complex planning environment and interaction between the partners in the supply chain [30].

To address these challenges, these questions can be raised:

- Why and how are digital technologies influencing supply chain planning?

- How do digital technologies affect roles and responsibilities in supply chain integration?

- How can digital technologies be designed to support supply chain planning?

\subsection{Decision systems}

Quantitative models and methods have been used for decades to provide decision support within operational production and logistics planning (see e.g., [11]). Many of 
these models have been made available to companies through commercially available Advanced Planning Systems [20]. Traditionally, most models for operational production, inventory, and distribution planning assume centralized decision making [6, 34]. Lean principles, however, advocate decentralized planning at the lowest possible planning level [5].

Digitalization and advances in information technology will make more data faster available to a decision maker, for example, through the extensive use of sensors monitoring state and surroundings of a production system (or product), or the Internet of Things (see §2.2). This will lead to more and more data-driven decisions, taking into account a much more comprehensive view of the production system [25].

To evaluate the impact these developments have on Lean principles, the following questions should be addressed:

- Will digitalization lead to more centralized decisions? It has long been recognized that systems need to be optimized as an entity, rather than optimizing subsystems [10]. Using large amounts of data in order to provide decisions for the entire system may push towards more centralized decisions.

- How can local decisions be coordinated in order to optimize the entire production system? Local decision makers may not only need access to vast amounts of data, but also help in understanding the consequences of their decisions. This applies especially in situations where e.g. local maximization of capacity utilization is counterproductive with respect to total cost within the production system.

\subsection{Supplier relationships}

While most research on Lean management has focused on intra-organizational applications of Lean principles [17], some attention had been paid to inter-organizational applications, e.g. to develop Lean suppliers and supply networks [8,23]. Digital communication and decision making with the need for and advantages of personal communication and participative decision making at both the suppliers and buying firm are, therefore, very important.

Furthermore, while some efforts have aimed at offering assistance to suppliers in order to improve their performance in the short run, strategic supplier development efforts have aimed at encouraging and enabling suppliers to develop their Lean capabilities by means of which the suppliers can continuously improve their Lean practices and performance [31]. Suppliers have been encouraged to find their "own Lean way" [26], thus preserving the autonomy of the suppliers. Finally, the development of Lean supplier networks has considered challenges of competitive rivalry, and for example, Toyota has taken care to create separate arenas for interaction with suppliers who are in direct competition [31], whereas Honda has had joint arenas. 
The potential of digital technologies to transform performance is now widely recognized, and a few contributions connect efforts at digital transformation with Lean supply principles [28], however, how digitalization can facilitate as well as hamper the manner in which manufacturing firms encourage, enable and enforce the development of Lean practices in their supplier relationships and networks is still challenging.

To address these challenges, the following questions can be raised:

- How can the key characteristics of Lean supplier relationships and networks be reconfigured considering digitalization, with the aim to improve the cost efficiency and the effectiveness of such efforts?

- How can digital technology be used for enabling and enforcing interaction, mutual trust, and knowledge-sharing routines between the suppliers and a buying customer, and between suppliers who may cooperate and compete?

- How can the integrity and autonomy of suppliers be preserved when they become connected in supplier networks by means of digital technologies with requirements for standardization?

\section{Conclusion}

In this paper, we have sketched the landscape for Lean and digital transformations. Interactions between the two improvement strategies and associated challenges are poorly understood in the current literature. This contribution sheds light on the landscape by classifying various challenges in four areas and proposing key questions for future research. The four areas are organizational design, supply-chain planning, decision systems, and supplier relationship. Although these areas correspond to established management disciplines, Lean- and digital transformations are multidisciplinary in their nature. Therefore, in addition to doing in-depth research within each area, researcher might work together in multidisciplinary team to create workable knowledge addressing practical challenges more holistically.

We hope our framework and research questions will trigger further discussions and research that aims to help organizations obtaining a correct strategy in their pathway towards Lean, learning and digital organization. For practitioners such a framework might be instrumental in clarifying the different aspects of a complex problem.

\section{References}

1. Ballé, M., Jones, D. T., Chaize, J., Flume, O., (2017), “The Lean Strategy”, McGraw Hill.

2. Bodrožić, Z. and Adler, P. S. (2018), "The Evolution of Management Models: A NeoSchumpeterian Theory", Administrative Science Quarterly, Vol. 63 No. 1, pp. 85-129.

3. Büyüközkan, G. and Göçer, F. (2018), "Digital Supply Chain: Literature review and a proposed framework for future research", Computers in Industry, Vol. 97 No. pp. 157-177. 
4. Cattaneo, L., Rossi, M., Negri, E., Powell, D. and Terzi, S. (2017), "Lean Thinking in the Digital Era" Product Lifecycle Management and the Industry of the Future, Springer International Publishing, Cham, pp. 371-381.

5. Christis, J. and Soepenberg, E. (2016), "Lowlands Socio-technical Design Theory and Lean Production" in Mohr, B. J. and Van Amelsvoort, P. (Eds.), Co-Creating Humane and Innovative Organizations, Global STS-D Network Press, Portland, ME, pp. 303-325.

6. Clark, A. J. and Scarf, H. (1960), "Optimal Policies for a Multi-Echelon Inventory Problem", Management Science, Vol. 6 No. 4, pp. 475-490.

7. Chopra, S. and Meindl, P. (2016), Supply Chain Management Strategy, Planning, and Operations, Pearson Education Limited, Essex.

8. Dyer, J. H. and Nobeoka, K. (2000), "Creating and Managing a High-Performance Knowledge-Sharing Network: The Toyota Case", Strategic Management Journal, Vol. 21 No. 3, pp. 345-367.

9. Fisher, M. L. (1997), "What Is the Right Supply Chain for Your Product?", Harvard Business Review, Vol. 75 No. 2, pp. 105-116.

10. Ganeshan, R., Jack, E., Magazine, M. J. and Stephens, P. (1999), "A Taxonomy of Supply Chain Management Research" in Tayur, S. R., Ganeshan, R. and Magazine, M. J. (Eds.), Quantitative Models for Supply Chain Management, Kluwer Academic Publishers, Norwell, MA, pp. 840-879.

11. Graves, S. C., Rinnooy Kan, A. H. G. and Zipkin, P. H. (1993), Logistics of Production and Inventory, Elsevier, Amsterdam.

12. Holtskog, H., Lied, L. H. and Ringen, G. (2018), "Coping with Technology - A future of Robots?" in Johnsen, H. C. G., Holtskog, H. and Ennals, J. R. (Eds.), Coping with the Future - rethinking assumptions for society, business and work, Routledge, Londen pp. 151-165.

13. Holweg, M. (2007), "The genealogy of Lean production", Journal of Operations Management, Vol. 25 No. 2, pp. 420-437.

14. Ingvaldsen, J. A. (2015), "Organizational Learning: Bringing the Forces of Production Back In", Organization Studies, Vol. 36 No. 4, pp. 423-444. side 15/15 Kompetanseprosjekt for næringslivet, mal for prosjektbeskrivelse 04.06.2018

15. Ingvaldsen, J. A. and Benders, J. (2016), "Lost in translation? The role of supervisors in Lean production", German Journal of Human Resource Management: Zeitschrift für Personalforschung, Vol. 30 No. 1, pp. 35-52.

16. Ivert, L. K., Dukovska-Popovska, I., Fredriksson, A., Dreyer, H. C. and Kaipia, R. (2015), "Contingency between S\&OP design and planning environment", International Journal of Physical Distribution \& Logistics Management, Vol. 45 No. 8, pp. 747-773.

17. Jasti, N. V. K. and Kodali, R. (2015), "A critical review of Lean supply chain management frameworks: proposed framework", Production Planning \& Control, Vol. 26 No. 13, pp. 1051-1068.

18. Kagermann, H., W. Wahlster, and J. Helbig, eds., Recommendations for implementing the strategic initiative Industrie 4.0 in Final report of the Industrie 4.0 Working Group. 2013: Frankfurt.

19. Lasi, H., et al., Industry 4.0. Business \& Information Systems Engineering, 2014. 6(4): p. 239-242.

20. Lebreton, B., Meyr, H., Rosič, H., Seipl, C. and Wetterauer, U. (2015), "Architecture of Selected APS" in Stadtler, H., Kilger, C. and Meyr, H. (Eds.), Supply Chain Management and Advanced Planning, Springer, Berlin, pp. 341-361.

21. Lee, E. A. (2015), "The Past, Present and Future of Cyber-Physical Systems: A Focus on Models", Sensors, Vol. 15 No. 3, pp. 4837-4869. 
22. Liker, J. K. (2004), The Toyota way: 14 management principles from the world's greatest manufacturer, McGraw-Hill, New York.

23. Macduffie, J. P. and Helper, S. (1997), "Creating Lean Suppliers: Diffusing Lean Production through the Supply Chain", California Management Review, Vol. 39 No. 4, pp. 118-151.

24. Martínez-Jurado, P. J. and Moyano-Fuentes, J. (2014), "Lean Management, Supply Chain Management and Sustainability: A Literature Review", Journal of CLeaner Production, Vol. 85 No. pp. 134-150.

25. McAfee, A. and Brynjolfsson, E. (2012), "Big Data: The Management Revolution", Harvard Business Review, Vol. 90 No. 10, pp. 60-68.

26. Netland, T. H. and Powell, D. J. (Eds.) (2017). The Routledge Companion to Lean Management, Routledge, New York.

27. Ohno, T. (1988), Toyota Production System: Beyond large-scale production, Productivity Press, New York.

28. Pinho, C. and Mendes, L. (2017), "IT in Lean-based manufacturing industries: systematic literature review and research issues", International Journal of Production Research, Vol. 55 No. 24, pp. 7524-7540.

29. Romero, D., Gaiardelli, P., Powell, D., Wuest, T., Thürer, M., (2018). Digital Lean CyberPhysical Production Systems: The Emergence of Digital Lean Manufacturing and The Significance of Digital Waste, "Advances in Production Management Systems", Proceedings of IFIP WG 5.7 International Conference, APMS 2018, Seoul, Korea, August 26-30, 2018.

30. Rudberg, M. and Thulin, J. (2009), "Centralised supply chain master planning employing advanced planning systems", Production Planning \& Control, Vol. 20 No. 2, pp. 158-167.

31. Sako, M. (2004), "Supplier Development at Honda, Nissan and Toyota: Comparative Case Studies of Organizational Capability Development", Industrial and Corporate Change, Vol. 13 No. 2, pp. 281-308.

32. Sanders, A., Elangeswaran, C. and Wulfsberg, J. (2016), "Industry 4.0 implies Lean manufacturing: Research activities in industry 4.0 function as enablers for Lean manufacturing", Journal of Industrial Engineering and Management, Vol. 9 No. 3, pp. 811-833.

33. Shah, R. and Ward, P. T. (2007), "Defining and developing measures of Lean production", Journal of Operations Management, Vol. 25 No. 4, pp. 785-805.

34. Simchi-Levi, D., Kaminsky, P. and Simchi-Levi, E. (2007), Designing and Managing the Supply Chain: Concepts, Strategies and Case Studies, McGraw-Hill, New York.

35. Womack, J. P. and Jones, D. T. (1996), Lean thinking: Banish waste and create wealth in your corporation, Simon \& Schuster, New York.

36. Womack, J. P., Jones, D. T. and Roos, D. (1990), "The Machine That Changed The World", Simon \& Schuster, New York. 